\title{
Effectiveness of chlorination and ozonation methods on pure cultures of floc-forming micro-organisms and activated sludge: A comparative study
}

\author{
Alejandro Caravelli', Leda Giannuzzi' and Noemí Zaritzky ${ }^{1,2 *}$ \\ ${ }^{1}$ Centro de Investigación y Desarrollo en Criotecnología de Alimentos (CIDCA). Facultad de Ciencias Exactas, \\ Universidad Nacional de La Plata - CONICET, 47 y 116, La Plata (1900) Argentina \\ ${ }^{2}$ Facultad de Ingeniería, Universidad Nacional de La Plata, 48 y 115, La Plata (1900) Argentina
}

\begin{abstract}
Chlorination is a very useful control method of filamentous bulking in activated sludge systems; however, it favours formation of undesirable compounds such as trihalomethanes. Other oxidants, such as ozone, could be used for bulking control. In view of the fact that chlorine and ozone are both non-selective chemical agents affecting filamentous and floc-forming micro-organisms, the determination of optimum dosage conditions becomes essential to minimise the impact produced on the activated sludge process. In this work, the effects of chlorine and ozone on the biomass concentration of activated sludge and on different parameters that characterise the microbial metabolic activity were compared. The following techniques were applied: Respirometry (oxygen uptake rate); and INT-dehydrogenase activity test carried out both by spectrophotometry (DHA) and image analysis (DHA $)$. The respirometric technique and the DHA test quantified oxidants action on the total respiratory activity of flocs; the image DHA test was applied to evaluate the specific action of the oxidants on filamentous micro-organisms. Additionally, plate count technique, respirometry and DHA test were correlated using chlorine and ozone experiments on pure cultures of a floc-forming micro-organism (Acinetobacter anitratus) to compare the effect of the oxidising agents on the metabolic activity and the viability of the micro-organisms. Ozone was found to have more intense antimicrobial action. In activated sludge, ozone reduced total biomass concentration by oxidising various components and causing cell lysis. An equation was proposed to estimate biomass concentration of activated sludge as a function of time and ozone dose rate; in contrast, at the doses applied, chlorine did not reduce the concentration of activated sludge biomass. In activated sludge, adequate conditions for both oxidants were identified under which the respiratory activity of filamentous micro-organisms could be considerably inhibited, causing the lowest possible impact on whole floc metabolic activity. An initial chlorine dose of $7.9 \mathrm{mgCl}_{2} \cdot \mathrm{gVSS}^{-1}$ for a contact time of $5 \mathrm{~min}$ (initial pulse $=6.0 \mathrm{mgCl} \cdot \ell^{-1}$ ), and a total ozone dose of $66.0 \mathrm{mgO} \cdot \mathrm{gVSS}^{-1}$ (ozone dose rate of $3.3 \mathrm{mgO} \cdot \mathrm{gVSS}^{-1} \cdot \mathrm{min}^{-1}$ for a contact time of $20 \mathrm{~min}$ ) were the most suitable conditions to control filamentous bulking.
\end{abstract}

Keywords: filamentous bulking, chlorine, ozone, INT-dehydrogenase activity, respirometry, image analysis, plate count

\section{Nomenclature}

$\mathrm{A}_{490} \quad$ Absorbance of the dye colorant extracted at 490 $\mathrm{nm}$ (AU, absorbance units)

$\mathrm{A}_{\mathrm{c}} \quad$ Area occupied by intracellular INT-formazan crystals

$\mathrm{A}_{\mathrm{T}} \quad$ Total area of the filamentous micro-organisms

CFU Colony forming units (CFU $\cdot \mathrm{m}^{\ell^{-1}}$ )

COD Chemical oxygen demand $\left(\mathrm{mgO}_{2} \cdot \ell^{-1}\right)$

$\mathrm{COD}_{\mathrm{B}} \quad$ Biomass chemical oxygen demand $\left(\mathrm{mgO}_{2} \cdot \ell^{-1}\right)$

$\mathrm{COD}_{\mathrm{S}} \quad$ Soluble chemical oxygen demand $\left(\mathrm{mgO}_{2} \cdot \ell^{-1}\right)$

$\mathrm{COD}_{\mathrm{T}} \quad$ Total chemical oxygen demand $\left(\mathrm{mgO}_{2} \cdot \ell^{-1}\right)$

$\mathrm{D}_{\mathrm{Cl}} \quad$ Initial chlorine dose $\left(\mathrm{mgCl}_{2} \cdot \mathrm{gVSS}^{-1}\right)$

DHA INT-dehydrogenase activity

DHA $_{\text {a }}$ INT-dehydrogenase activity measured by spectrophotometry (A.U $\ell \cdot \mathrm{gVSS}^{-1} \cdot \mathrm{h}^{-1}$ )

DHA $_{\text {a(control) }}$ INT-dehydrogenase activity measured by spectrophotometry in untreated samples $\left(\mathrm{A} . \mathrm{U} \cdot \ell \cdot \mathrm{gVSS}^{-1} \cdot \mathrm{h}^{-1}\right)$

* To whom all correspondence should be addressed.

疋 $+(54-221)$ 4249287; fax: $+(54-221)$ 4254853;

e-mail:zaritzky@,volta.ing.unlp.edu.an

Received 16 January 2005; accepted in revised form 7 August 2006.
DHA

INT-dehydrogenase activity measured by spectrophotometry in samples treated with chlorine or ozone $\left(\right.$ A.U $\cdot \ell \cdot \mathrm{gVSS}^{-1} \cdot h^{-1}$ )

DHA $_{\mathrm{i}} \quad$ INT-dehydrogenase activity measured by image analysis (dimensionless)

DHA $_{\text {i(control) }}$ INT-dehydrogenase activity measured by image analysis in untreated samples (dimensionless)

DHA $_{\text {i(treated) }}$ INT-dehydrogenase activity measured by image analysis in samples treated with chlorine or ozone (dimensionless)

$\mathrm{D}_{\mathrm{oz}} \quad$ Total ozone dose $\left(\mathrm{mgO}_{3} \cdot \mathrm{gVSS}^{-1}\right)$

FR Bacterial respiratory activity fraction (dimensionless)

$\mathrm{FR}_{\text {DHAa }} \quad$ Bacterial respiratory activity fraction obtained by spectrophotometry (dimensionless)

$\mathrm{FR}_{\text {DHAi }} \quad$ Bacterial respiratory activity fraction obtained by image analysis (dimensionless)

$\mathrm{FR}_{\mathrm{OUR}} \quad$ Bacterial respiratory activity fraction based on respirometric technique (dimensionless)

Correction factor for the dilution caused by formaldehyde addition

k Specific rate of biomass decay $\left(\mathrm{min}^{-1}\right)$ 


\begin{tabular}{|c|c|}
\hline OAR & Ozone application rate $\left(\mathrm{mgO}_{3} \cdot \ell^{-1} \cdot \mathrm{min}^{-1}\right)$ \\
\hline ODR & Ozone dose rate $\left(\mathrm{mgO}_{3} \cdot \mathrm{gVSS}^{-1} \cdot \mathrm{min}^{-1}\right)$ \\
\hline OUR & Oxygen uptake rate (respirometry) $\left(\mathrm{mgO}_{2} \cdot \ell^{-1} \cdot \mathrm{h}^{-1}\right)$ \\
\hline OUR $_{\text {(chlorine) }}$ & $\begin{array}{l}\text { Oxygen uptake rate in chlorinated samples } \\
\left(\mathrm{mgO}_{2} \cdot \ell^{-1} \cdot h^{-1}\right)\end{array}$ \\
\hline OUR (control) $_{1}$ & Control oxygen uptake rate $\left(\mathrm{mgO}_{2} \cdot \ell^{-1} \cdot h^{-1}\right)$ \\
\hline OUR (ozone) $_{\text {(a) }}$ & $\begin{array}{l}\text { Oxygen uptake rate in ozonated samples } \\
\left(\mathrm{mgO}_{2} \cdot \ell^{-1} \cdot h^{-1}\right)\end{array}$ \\
\hline OUR $_{(\text {treated) }}$ & $\begin{array}{l}\text { Oxygen uptake rate in samples treated with chlo- } \\
\text { rine or ozone }\left(\mathrm{mgO}_{2} \cdot \ell^{-1} \cdot h^{-1}\right)\end{array}$ \\
\hline RA & Respiratory activity \\
\hline 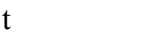 & Time (h) \\
\hline TOF & Total ozone feed $\left(\mathrm{mgO}_{3} \cdot \ell^{-1}\right)$ \\
\hline $\mathrm{v}$ & $\begin{array}{l}\text { Volume of the solvent acetone/tetrachloroethylene } \\
(\mathrm{m} \ell)\end{array}$ \\
\hline $\mathrm{V}$ & Volume of the INT-treated sample $(\mathrm{m} \ell)$ \\
\hline VSS & Concentration of volatile suspended solids $\left(\mathrm{gVSS} \cdot \ell^{-1}\right)$ \\
\hline $\mathrm{X}$ & Biomass concentration $\left(\mathrm{gVSS} \cdot \ell^{-1}\right)$ \\
\hline$X_{0}$ & Initial biomass concentration $\left(\mathrm{gVSS} \cdot \ell^{-1}\right)$ \\
\hline
\end{tabular}

\section{Introduction}

Filamentous bulking is a problem that frequently occurs in activated sludge wastewater treatment plants that can affect the performance of these systems. Chlorination is a very useful control method; however, it favours formation of undesirable compounds such as trihalomethanes (Switzenbaum et al., 1992), which may be dangerous to human health (Reynolds et al., 1989).

Other oxidants, such as ozone and hydrogen peroxide, could be used for bulking control in activated sludge systems (Wanner, 1994). Ozone is widely used in wastewater disinfection, mainly in drinking water treatment plants (Facile et al., 2000), although limited information is available in the literature about its use and effectiveness to control filamentous bulking. Van Leeuwen and Pretorius (1988) have reported that filamentous bulking can be controlled by continuous ozone dosage in the aerobic zone of a small pilot-scale activated sludge system. Saayman et al. (1996) working on a full-scale activated sludge plant for biological nutrient removal, have observed the consistent positive effect of ozone on bulking control.

The oxidising agents must diffuse toward the surface of the micro-organism and then permeate into the membrane and cytoplasm. Inactivation or loss of viability would occur when vital constituents would suffer a certain level of irreversible damage (Hunt and Mariñas, 1999).

Chlorine has been verified to exert a wide range of disruptive effects such as oxidative decarboxylation of amino acids (Pereira et al., 1973), inhibition of enzymes involved in intermediary metabolism (Camper and McFeters, 1979), inhibition of protein biosynthesis (Benarde et al., 1967), damage to chromosomal DNA (Shih and Lederberg, 1976), inhibition of membrane-mediated active transport processes and respiratory activity (Camper and McFeters, 1979), and uncoupling of oxidative phosphorylation (Venkobachar et al., 1977). Sharma and Venkobachar (1979) were of the opinion that chlorine could oxidise the N-terminal amino groups of proteins within the cell wall, which would alter the wall strength and thus kill the cells. More recently, White (1999) indicated that chlorine diffuses through the cell walls, produces a dysfunction in internal enzymes and hence inactivates cells.

Different studies have suggested that ozone attack the bacterial surface (Christensen and Giese, 1954) altering the per- meability of the membrane and ultimately resulting in leakage of cell contents (Scott and Lesher, 1963). Ishizaki et al. (1987) suggested that ozone was able to diffuse through the cell membrane and react with bio-molecules and indicated that damage to chromosomal DNA might be one of the reasons for inactivation of $E$. coli. Other authors working with $E$. coli indicated that lysis of the inactivated cells can result after prolonged ozonation (Perrich et al., 1975; Hamelin et al., 1978; Hunt and Mariñas, 1999). White (1999) indicated that ozone disinfection is a direct result of cell wall disintegration and cell lysis.

There is abundant information in the literature referring to bacterial inactivation using chlorine or ozone in water and wastewater (Ward et al., 1984; Hunt and Mariñas, 1999; Baker et al., 2002; Xu et al., 2002; Gehr et al., 2003; Tree et al., 2003); however, it is very difficult to compare the performance of these oxidising agents because of the different experimental conditions used. Many factors may affect the kinetics of microbial inactivation by oxidising agents and the success of the operation of disinfection, among which can be mentioned the physicochemical quality of the wastewater, the hydraulic functioning of the contact reactors and the decomposition kinetics of oxidants due to the presence of specific organic and inorganic components in the water (Hassen et al., 2000). Recent studies indicate that ozone is more effective than chlorine in the disinfection process (Baker et al., 2002; Freese et al., 2003).

In view of the fact that chlorine and ozone are both nonselective chemical agents affecting filamentous and floc-forming micro-organisms (Van Leeuwen, 1992), the determination of optimum dosage conditions becomes essential to minimise the impact produced on the activated sludge process. The purpose is to suitably control filamentous bacteria while minimising the effect on the floc-forming ones. An important step toward that aim is to analyse the effect of oxidising agents on the biomass concentration of activated sludge and on parameters of microbial metabolic activity that allow identification of the specific actions of the oxidants on the two micro-organism types mentioned above.

The total biomass in activated sludge systems can be determined as volatile suspended solids (VSS), while the microbial metabolic activity can be quantified by several techniques, such as, respirometry (OUR, oxygen uptake rate) and by tests determining the dehydrogenase activity of the electron transport system (ETS) (Kim et al., 1994).

The ETS is a common component to metabolic pathways of virtually all bacteria, including lithotrophs and methylotrophs, facultative and strict anaerobes, and aerobic heterotrophs (Tabor and Neihof, 1982). The ETS activity can be measured by the use of surrogate electron acceptors, such as the tetrazolium salts which, once reduced, allow the proportion of cells having metabolic activity in a sample to be microscopically distinguished from non-respiring cells (Rodriguez et al., 1992; Roslev and King, 1993; Schaule et al., 1993).

In the case of INT (2-(p-iodophenyl)-3-(p-nitrophenyl)5-phenyltetrazolium chloride), the technique comprises INT reduction to INT-formazan (INTF) by active bacterial ETS, a test known as INT-dehydrogenase activity (DHA). INTF is deposited in active cells as dark intracellular crystals that are quantified by spectrophotometric techniques after extraction in proper solvent, or by microscopic observation of prepared specimens coupled with image analysis of INTF crystals. The INTdehydrogenase activity was shown to be related to respiration (Kim et al., 1994).

In activated sludge, the spectrophotometrically quantifiedDHA test $\left(\mathrm{DHA}_{\mathrm{a}}\right)$ and the respirometric technique are both able 
to determine the effect of oxidising agents on the overall respiratory activity (RA) of the activated sludge. However, they are unable to discriminate the specific effects on filamentous and floc-forming bacteria. The image analysis quantified-DHA test $\left(\mathrm{DHA}_{\mathrm{i}}\right)$ allows the specific effect of biocide agents to be determined on the filamentous micro-organisms present on the surface of activated sludge flocs (Caravelli et al., 2004). These methods, based on the measurement of physiological parameters, allow a rapid assessment of the effect of the chemical oxidants on the metabolic activity of activated sludge.

In addition, the biocide action of oxidants can be determined by the plate count method. This test is able to evaluate the efficiency of the disinfection process of pathogenic micro-organisms, though it can also be applied to activated sludge flocs. For the latter purpose, a sonication treatment is required first in order to dissociate microbial aggregates and maximise the recovery of the colony forming unit (CFU) (Maurines-Carboneill et al., 1998). However, the plate count technique can only be applied to floc-forming micro-organisms and not to filamentous bacteria since their presence in activated sludge makes data interpretation difficult. Moreover, the plate count method is a laborious technique requiring at least $24 \mathrm{~h}$ to collect the results. A comparison between this technique and those determining the microbial metabolic activity (OUR, DHA ) has not been reported in literature. Therefore, studies using pure cultures of bacteria treated with various oxidants would contribute to determine the correlation degree between these techniques and to discern the possible mechanisms of action for each of these oxidants.

The objectives of the present study were to:

- Quantify the effects of chlorine and ozone on total biomass concentration of activated sludge

- Compare different methods that evaluate the antimicrobial action of these oxidants: plate count technique, respirometry and the INT-dehydrogenase activity test using pure cultures of a floc-forming micro-organism (Acinetobacter anitratus) under chlorination and ozonation conditions

- Compare the effect of various chlorination and ozonation conditions on the total respiratory activity (RA) of activated sludge and on the RA of the filamentous micro-organisms present in the flocs

- Determine adequate oxidant doses that allow control of filamentous bulking causing the lowest possible impact on flocforming micro-organisms.

\section{Materials and methods}

\section{Pure culture experiments}

Pure cultures of the floc-forming bacterium Acinetobacter anitratus were utilised to compare different methods that evaluate the antimicrobial action of ozone and chlorine. This strain was isolated from one of the lab-scale activated sludge wastewater treatment plants of our Institute CIDCA (Center of Research and Development in Food Cryotechnology, UNLP-CONICET, Argentina) by Contreras et al. (2000). These authors used the laboratory plant fed with a wastewater model system of the potato processing industry and applied an isolation technique proposed by Crabtree and McCoy (1967). This strain was identified using the biochemical test system Sensident-E (Merck). Acinetobacter is a floc-forming bacterium (Jenkins et al., 1993) found in several industrial activated sludge systems (Converti et al., 1995), particularly in potato processing plants (Van der Waarde et al., 2001). In previous work published it is reported that the genus Acinetobacter was responsible for enhanced biological phosphate removal (EBPR) in activated sludge (Buchan, 1983; Lötter, 1985; Kerdachi and Healey, 1987); however, according to more recent information (Mino et al., 1998) Acinetobacter can no longer be considered as the principle organism responsible for the EBPR process.

The following culture medium was used for pure cultures: monohydrate citric acid, $3480 \mathrm{mg} \cdot \ell^{-1} ;\left(\mathrm{NH}_{4}\right)_{2} \mathrm{SO}_{4}, 1000 \mathrm{mg} \cdot \ell^{-1}$; $\mathrm{MgSO}_{4} .7 \mathrm{H}_{2} \mathrm{O}, 400 \mathrm{mg} \cdot \ell^{-1} ; \mathrm{CaCl}_{2} .2 \mathrm{H}_{2} \mathrm{O}, 50 \mathrm{mg} \cdot \ell^{-1} ; \mathrm{KH}_{2} \mathrm{PO}_{4}, 250$ $\mathrm{mg} \cdot \ell^{-1} ; \mathrm{Na}_{2} \mathrm{HPO}_{4} \cdot 12 \mathrm{H}_{2} \mathrm{O}, 1000 \mathrm{mg} \cdot \ell^{-1} ;$ Vitamin B12, $100 \mu \mathrm{g} \cdot \ell^{-1}$; $\mathrm{FeSO}_{4} \cdot 7 \mathrm{H}_{2} \mathrm{O}, 15 \mathrm{mg} \cdot \ell^{-1} ; \mathrm{ZnSO}_{4} \cdot 7 \mathrm{H}_{2} \mathrm{O}, 5 \mathrm{mg} \cdot \ell^{-1} ; \mathrm{MnSO}_{4} \cdot \mathrm{H}_{2} \mathrm{O}$, $3 \mathrm{mg} \cdot \ell^{-1} ; \mathrm{CuSO}_{4} .5 \mathrm{H}_{2} \mathrm{O}, 0.75 \mathrm{mg} \cdot \ell^{-1} ; \mathrm{CoCl}_{2} \cdot 6 \mathrm{H}_{2} \mathrm{O}, 0.15 \mathrm{mg} \cdot \ell^{-1}$; $\left(\mathrm{NH}_{4}\right)_{6} \mathrm{Mo}_{7} \mathrm{O}_{24} \cdot 4 \mathrm{H}_{2} \mathrm{O}, 0.5 \mathrm{mg} \cdot \ell^{-1} ; \mathrm{BO}_{3} \mathrm{H}_{3}, 0.1 \mathrm{mg} \cdot \ell^{-1} ; \mathrm{KI}, 0.1 \mathrm{mg} \cdot \ell^{-1}$. The medium $(10 \ell)$ was sterilised at $121^{\circ} \mathrm{C}$ for 60 min except for Vitamin B12, which was sterilised by membrane filtration $(0.45$ $\mu \mathrm{m}$ Millipore HA) and then added to the sterile medium.

A chemostat apparatus with the described culture medium $(1 \ell)$ was initially inoculated with a pure culture (agar slant inocula) and operated aseptically. Growth was at $30^{\circ} \mathrm{C}$ with an air flow rate of $2 \ell \cdot \mathrm{min}^{-1}$, a rotor speed of $600 \mathrm{r} \cdot \mathrm{min}^{-1}$ and the dissolved oxygen concentration was above $2 \mathrm{mgO}_{2} \cdot \ell^{-1}$.

The chemostat was operated as a batch for several hours until growth of micro-organisms was observed (biomass concentration of $\left.0.5 \mathrm{gVSS} \cdot \ell^{-1}\right)$; then, pumping of fresh culture medium was begun. Dilution rates ranged between 0.11 to $0.13 \mathrm{~h}^{-1}$. The system was considered to run under steady state conditions after operating for a period of at least five residence times (Pirt, 1975).

The $\mathrm{pH}$ of the culture medium was adjusted to 7.0 with $\mathrm{NaOH}$ before autoclaving. A constant $\mathrm{pH}$ of 7.0 was maintained throughout the course of chemostat operation by the automatic addition of $\mathrm{H}_{2} \mathrm{SO}_{4}(1 \mathrm{M})$.

\section{Activated sludge experiments}

Experiments with activated sludge were conducted on a complete mix continuous flow laboratory reactor consisting of a $2.5 \ell$ aeration basin coupled with a clarifier $(1 \ell)$.

A model system corresponding to a wastewater of a potato processing plant was prepared every $2 \mathrm{~d}$. The stock wastewater was obtained by immersing potato cubes $1 \mathrm{~cm}^{2}$ in tap water at room temperature for $24 \mathrm{~h}$. The stock wastewater was diluted to produce a chemical oxygen demand (COD) of $1000 \mathrm{mg} \cdot \ell^{-1}$; the solids content of the wastewater model was negligible. The $\mathrm{pH}$ was 6.0 and the nitrogen and phosphorus content were 75 and 10.5 $\mathrm{mg} \cdot \ell^{-1}$ respectively with COD/N/P ratio $100 / 7.5 / 1.1$; this ratio is commonly accepted as necessary for biomass growth (Winkler, 1996). Previous studies indicated that citrate was the most important component of this wastewater followed by other organic acids and glucose (Contreras et al., 2000). No inert (soluble minerals) were present in the stock wastewater (Bertola et al., 1999).

Initially, the activated sludge reactor was filled with the stock wastewater and operated under batch conditions. Once microbial growth was evident (biomass concentration of $0.5 \mathrm{gVSS} \cdot \ell^{-1}$ ), the reactor was continuously fed with substrate using a dosing pump. The operating conditions were as follows: temperature of $20 \pm$ $2^{\circ} \mathrm{C}$, hydraulic residence time of $36 \mathrm{~h}$, and mean cell residence time of $21 \mathrm{~d}$. Aeration and mixing were supplied by aerators; air was introduced through porous diffusers at the bottom of the aeration basin. To ensure steady state, microscopic observations of the activated sludge were performed and three replicated samples were used to determine dissolved oxygen concentration and biomass concentration, until the obtained values deviated less than 10 to15\% according to Barbusińsky and Kościelniak (1995).

Microscopic observations were performed with the aid of a Leica (DMLB, Germany) light microscope equipped with phase 
contrast optics and a built-in camera. Activated sludge specimens were prepared as wet mounts and examined at $1000 \mathrm{X}$ magnification.

\section{Determination of biomass concentration}

Biomass concentration of the pure culture (A. anitratus) and activated sludge was measured by chemical oxygen demand (COD) and transformed into volatile suspended solids (VSS) using a calibration curve previously determined (Contreras et al., 2002). COD measurements were performed with a commercial kit (Hach Corp., Loveland, USA). The use of COD to determine biomass concentration was reported by many authors (Bullock et al., 1996; Contreras et al., 2002). When the chemostat apparatus and the continuous flow activated sludge reactor was considered to run under steady state conditions, samples were drawn to measure the total chemical oxygen demand $\left(\mathrm{COD}_{\mathrm{T}}\right)$. Another portion was filtered through a 0.45 $\mu \mathrm{m}$ membrane (Millipore HA) and soluble chemical oxygen demand $\left(\mathrm{COD}_{\mathrm{S}}\right)$ was measured. Biomass concentration $\left(\mathrm{COD}_{\mathrm{B}}\right)$ was calculated as the difference between $\mathrm{COD}_{\mathrm{T}}$ and $\mathrm{COD}_{\mathrm{S}}$ (Contreras et al., 2002).

\section{Microbial inactivation by chlorine application}

Chlorination assays were carried out using A. anitratus pure culture and activated sludge resuspended in buffer phosphate $(0.03 \mathrm{M}, \mathrm{pH}=7.0)$. Samples of $180 \mathrm{~m} \ell$ from the A. anitratus pure culture (biomass concentration $=630$ to $920 \mathrm{mgVSS} \cdot \ell^{-1}$ ) were placed in a magnetically-stirred container, at a controlled temperature of $30^{\circ} \mathrm{C}$, and then treated with an initial pulse of sodium hypochlorite to obtain chlorine concentration ranging between 5.4 to $8.5 \mathrm{mgCl}_{2} \cdot \ell^{-1}$, equivalent to the range of initial chlorine dose $\left(\mathrm{D}_{\mathrm{Cl}}\right): 8.5$ to $18.5 \mathrm{mgCl} \cdot \mathrm{gVSS}^{-1}$. Contact times with chlorine ranged between 2 to $20 \mathrm{~min}$. The residual chlorine was removed with sodium thiosulphate.

For activated sludge, the chlorination tests were carried out under the same conditions, but the biomass concentration ranged between 700 and $760 \mathrm{mgVSS} \cdot \ell^{-1}$, the initial concentration range of chlorine was: 3.3 to $6.0 \mathrm{mgCl}_{2} \cdot \ell^{-1}\left(\mathrm{D}_{\mathrm{Cl}}=4.7\right.$ to $\left.7.9 \mathrm{mgCl}_{2} \cdot \mathrm{gVSS}^{-1}\right)$ and the contact times with chlorine ranged between 1 and $25 \mathrm{~min}$. These conditions were determined from previous results. All the experiments were run in duplicate.

\section{Microbial inactivation by ozone application}

A. anitratus pure culture micro-organisms and activated sludge micro-organisms were separated from the culture medium by centrifugation and subsequent re-suspension in phosphate buffer $0.03 \mathrm{M}(\mathrm{pH}=7.0)$, prior to the inactivation tests.

A laboratory ozone generator (ADELO ARGENTINA, Argentine Association of Ozone, Buenos Aires) was used with a gas flow rate of $2.05 \ell \cdot \mathrm{min}^{-1}$ and an ozone concentration of $48 \mathrm{ppm}\left(102.8 \mu \mathrm{gO}_{3} \cdot \ell^{-1}\right)$ according to the electrochemical-ozone analyser (International Xilix S.A., Model DCMIV/O, Argentina) yielding $0.210 \mathrm{mgO}_{3} \cdot \mathrm{min}^{-1}$. The gas stream was continuously bubbled through a porous diffuser for several contact times ranging between 2.5 to $30 \mathrm{~min}$ in containers with $45 \mathrm{~m} \ell$ (pure culture or activated sludge), under magnetic stirring and controlled temperature $\left(30^{\circ} \mathrm{C}\right)$. The ozone application rate $(\mathrm{OAR}$, $\left.4.66 \mathrm{mgO}_{3} \cdot \ell^{-1} \cdot \mathrm{min}^{-1}\right)$ was calculated considering the volume of ozonated sample in the containers $(45 \mathrm{~m} \ell)$. The total ozone feed applied within a specified time period (TOF, $\left.\mathrm{mgO}_{3} \cdot \ell^{-1}\right)$ was calculated by multiplying the ozone application rate by the ozona- tion time utilised ( 2.5 to $30 \mathrm{~min}$ ), and the values ranged between 11.6 and $139.8 \mathrm{mgO}_{3} \cdot \ell^{-1}$.

The ozone dose rate $\left(\mathrm{ODR}, \mathrm{mgO}_{3} \cdot \mathrm{gVSS}^{-1} \cdot \mathrm{min}^{-1}\right)$ was defined as the ratio between the ozone application rate (OAR) and the initial biomass concentration $\left(\mathrm{gVSS} \cdot \ell^{-1}\right)$, and the total ozone dose $\left(\mathrm{D}_{\mathrm{oz}}, \mathrm{mgO}_{3} \cdot \mathrm{gVSS}^{-1}\right)$ was calculated by multiplying the ozone dose rate by the ozonation time utilised ( 2.5 to $30 \mathrm{~min}$ ).

Individual experiments were carried out for each contact time in order to consistently maintain the same volume during ozonation. Ozone concentration in aqueous phase was quantified by the indigo colorimetric method (indigo trisulphonate) (Standard Methods, 1992). For each experiment, initial ozone concentration was measured in phosphate buffer $\mathrm{pH}=7.0\left(30^{\circ} \mathrm{C}\right)$ without micro-organisms.

In phosphate buffer $\mathrm{pH}=7.0\left(30^{\circ} \mathrm{C}\right)$ without microorganisms, the dissolved ozone concentration measured was $20 \mu \mathrm{gO}_{3} \cdot \ell^{-1}$ for an ozonation period of $2.5 \mathrm{~min}$ and $26 \mu \mathrm{gO}_{3} \cdot \ell^{-1}$ since $5 \mathrm{~min}$ of ozone dosage. For $A$. anitratus pure culture, the total ozone feed (TOF) ranged between 11.6 to $93.2 \mathrm{mgO}_{3} \cdot \ell^{-1}$ for the assayed contact times ( 2.5 to $20 \mathrm{~min}$ ) and the total ozone dose $\left(\mathrm{D}_{\mathrm{oz}}\right.$ ) ranged between 14.0 to $216.7 \mathrm{mgO}_{3} \cdot \mathrm{gVSS}^{-1}$ for the range of initial biomass concentration utilised ( 430 to $\left.830 \mathrm{mgVSS} \cdot \ell^{-1}\right)$. For activated sludge, the TOF ranged between 23.3 to $139.8 \mathrm{mgO}_{3} \cdot \ell^{-1}$ (contact times: 5 to $30 \mathrm{~min}$ ), the ozone dose rate (ODR) ranged between 3.3 to $6.1 \mathrm{mgO}_{3} \cdot \mathrm{gVSS}^{-1} \cdot \mathrm{min}^{-1}$ (initial biomass concentration: 760 to $1400 \mathrm{mgVSS} \cdot \ell^{-1}$ ) and the $\mathrm{D}_{0 z}$ ranged between 16.5 and $183.0 \mathrm{mgO}_{3} \cdot \mathrm{gVSS}^{-1}$ for the tested contact times. The residual ozone was removed with sodium thiosulphate. All the experiments were run in duplicate.

\section{Effect of oxidising agents on activated sludge biomass concentration}

The effect of oxidising agents, chlorine and ozone, on the activated sludge biomass concentration was evaluated by COD measurements, then the $\mathrm{COD}_{\mathrm{B}}$ values (biomass COD) were transformed into VSS using a calibration curve previously determined (Contreras et al., 2002) as was indicated above.

These assays were performed in a magnetically-stirred container with activated sludge resuspended in buffer phosphate $(0.03 \mathrm{M}, \mathrm{pH}=7.0)$. For chlorine treatment, different initial concentrations of sodium hypochlorite ranging between 3.3 to 6.0 $\mathrm{mgCl}_{2} \cdot \ell^{-1}$ were applied, equivalent to $4.7-7.9 \mathrm{mgCl}_{2} \cdot \mathrm{gVSS}^{-1}$, and the contact times with chlorine ranged between 1 to $25 \mathrm{~min}$. For ozone treatment, the TOF ranged between 23.3 to $139.8 \mathrm{mgO}_{3} \cdot \ell^{-1}$ for the assayed contact times ( 5 to $30 \mathrm{~min}$ ) and the ODR ranged between 2.4 to $8.8 \mathrm{mgO} \cdot \mathrm{gVSS}^{-1} \cdot \mathrm{min}^{-1}$ (initial biomass concentration: 530 to $\left.1940 \mathrm{mgVSS} \cdot \ell^{-1}\right)$. The ozone concentration measured in buffer phosphate without micro-organisms was 26 $\mu \mathrm{gO}_{3} \cdot \ell^{-1}$ for the different contact times.

The residual oxidising agent (chlorine or ozone) was removed with sodium thiosulphate.

\section{Techniques used to analyse the microbial inactiva- tion effect of chlorine and ozone}

In the case of pure cultures of $A$. anitratus, the respiratory activity of the bacteria was determined by respirometry (OUR) and the spectrophotometrically quantified-DHA test (DHA); the culture viability was measured by means of the plate count technique. These techniques were tested in a pure culture with the purpose of comparing the effect of the oxidising agents on the metabolic activity and the viability of the micro-organisms.

In the case of activated sludges containing filamentous and 
floc-forming micro-organisms, the methods used to assess the effects of chlorine and ozone on metabolic activity in the flocs were: respirometry, DHA assay and the INT-dehydrogenase activity test by image analysis $\left(\mathrm{DHA}_{\mathrm{i}}\right.$ ) for filamentous microorganisms.

\section{Microbial counts}

Micro-organisms from A. anitratus pure culture, resuspended in buffer phosphate $(0.03 \mathrm{M}, \mathrm{pH}=7)$, were counted after the treatments with chlorine or ozone. Samples $(1 \mathrm{~m} \ell)$ were serially diluted in sterile water and streaked onto casein glycerol yeast extract agar (CGY). Petri dishes containing the diluted samples plus CGY were incubated at $30^{\circ} \mathrm{C}$ for $2 \mathrm{~d}$. Concentrations of micro-organisms were determined by counting the number of colony forming units $\left(\mathrm{CFU} \cdot \mathrm{m}^{-1}\right)$.

\section{Determination of the INT-dehydrogenase activity}

The INT-dehydrogenase activity of the bacteria was determined by the:

- Spectrophotometric method

- Image analysis method

These techniques were optimised and described by Caravelli et al. (2004).

The INT incubation tests were carried out in $1.5 \mathrm{~m} \ell$ microcentrifuge tubes in the presence of an oxidisable exogenous substrate. Citric acid $(3.5 \% \mathrm{w} / \mathrm{v}, \mathrm{pH}=7.0)$ for $A$. anitratus pure culture and a model wastewater from a potato processing plant in the case of activated sludge were used as exogenous substrates. Samples of $0.4 \mathrm{~m} \ell$ of pure culture or $0.7 \mathrm{~m} \ell$ of activated sludge (resuspended in buffer phosphate, $0.03 \mathrm{M}, \mathrm{pH}=7.0$ ) together with $0.2 \mathrm{~m} \ell$ or $0.5 \mathrm{~m} \ell$ of the corresponding oxidisable substrate were incubated under the following conditions: INT $=0.15 \mathrm{~g} \cdot \ell^{-1}$, incubation time $=50 \mathrm{~min}$, room temperature $=20^{\circ} \mathrm{C}, \mathrm{pH}=7.0$. Buffer phosphate $0.03 \mathrm{M}(\mathrm{pH}=7.0)$ was added to fill microcentrifuge tubes and to minimise any oxygen interference during incubation. After the incubation period, the reaction was stopped by addition of formaldehyde $40 \%$.

Spectrophotometric method: A sample $(1 \mathrm{~m} \ell)$ of the mixture treated with INT was centrifuged at $14000 \mathrm{r} \cdot \mathrm{min}^{-1}(5 \mathrm{~min})$ and then the supernatant was discarded. The INTF crystals were extracted by adding $1 \mathrm{~m} \ell$ of an acetone/tetrachloroethylene solution $(1.5 / 1 \mathrm{v} / \mathrm{v})$. Extraction of INTF was done at room temperature for $30 \mathrm{~min}$. Samples were then centrifuged (14 000 $\mathrm{r} \cdot \mathrm{min}^{-1}$, for $5 \mathrm{~min}$ ) to retain the supernatant and absorbance at $490 \mathrm{~nm}$ (spectrophotometer DU 650 Beckman) was measured in order to determine the extracted colorant concentration. Absorbance measurements were used in the following equation:

$$
D H A_{a}=\frac{A_{490} v}{V C t j}
$$

where:

DHA correspond to the INT-dehydrogenase activity quantified by spectrophotometry

$\mathrm{A}_{490}$ is the absorbance of formazan extracted at $490 \mathrm{~nm}$ (AU, absorbance units)

$\mathrm{v}$ is the solvent volume $(\mathrm{m} \ell)$

$\mathrm{V}$ is the volume of incubated sample with INT $(\mathrm{m} \ell)$

$\mathrm{X}$ is the initial biomass concentration $\left(\mathrm{gVSS} \cdot \ell^{-1}\right)$

$\mathrm{t}$ is the incubation time $(\mathrm{h})$ j corresponds to the correction factor that takes into account the additional dilution caused by formaldehyde addition

The spectrophotometric method was applied to pure cultures and to activated sludges treated with chlorine or ozone. In pure cultures, this technique was correlated with respirometry and plate count technique, while in activated sludge it allowed to quantify the effect of the oxidising agents on global RA of the flocs.

Image analysis method: In activated sludges, floc-forming and filamentous micro-organisms grow together, thus the image analysis method was applied to determine the effect of oxidising agents on filamentous bacteria. This method is a modified version of a technique by Logue et al. (1983). It must be pointed out that image analysis cannot be applied to floc-forming microorganisms in activated sludge because the size, shape and arrangement of these bacteria in the floc (internal zone) do not allow visualisation of INTF crystals.

Samples of activated sludge were incubated with INT and after the reaction was stopped with formaldehyde, preparations for microscopic observations were made using malachite green $0.05 \%$ (w/v) as counter-stain. A microscope Leica DMLB (Germany) fitted with a photographic camera was used; the captured images were analysed with Global Lab Image Version 2.10 software. Calculated parameters were the area occupied by INTF intracellular crystals of filamentous micro-organisms $\left(\mathrm{A}_{\mathrm{c}}\right)$, the total area of such micro-organisms $\left(\mathrm{A}_{\mathrm{T}}\right)$ and its ratio $\mathrm{DHA}_{\mathrm{i}}=$ $\mathrm{A}_{\mathrm{c}} / \mathrm{A}_{\mathrm{T}}$ named INT-dehydrogenase activity quantified by image analysis. The image analysis method was applied to samples of activated sludge treated with chlorine or ozone for determining the RA of the filamentous micro-organisms present in the flocs.

\section{Respirometry}

The respirometry allows quantifying theOUR; this technique has been used to study toxicity of several chemical agents (Ros, 1993; Vanrolleghem et al., 1994).

Respirometric assays were conducted with A. anitratus pure culture and also with activated sludge (resuspended in buffer phosphate $0.03 \mathrm{M}, \mathrm{pH}=7.0$ ) treated with chlorine or ozone. The respirometric technique was described by Caravelli et al. (2003). The equipment used included a vessel containing a polarographic oxygen probe (YSI Incorp., Ohio, USA), an aerator, magnetic stirring and temperature control $\left(30^{\circ} \mathrm{C}\right)$. For pure cultures, OUR $\left(\mathrm{mgO}_{2} \cdot \ell^{-1} \cdot \mathrm{h}^{-1}\right)$ was measured by placing $20 \mathrm{~m} \ell$ of the bacteria suspension (buffer phosphate: 0.03 $\mathrm{M}, \mathrm{pH}=7.0)$ in the respirometer. A volume of $1 \mathrm{m \ell}$ citric acid solution $(3.5 \% \mathrm{w} / \mathrm{v}, \mathrm{pH}=7.0)$ was added as oxidisable substrate and, after $1 \mathrm{~min}$ of contact, the system was aerated for $1 \mathrm{~min}$. After aeration had ceased, the OUR (control) was determined. Samples treated with chlorine or ozone $(20 \mathrm{~m} \ell)$ were placed in the respirometer and the residual oxidising agent was removed with sodium thiosulphate. A volume of $1 \mathrm{~m} \ell$ citric acid solution was added and then the system was aerated $(1 \mathrm{~min})$. Once aeration ceased, OUR (chlorine) $_{\text {or OUR }}$ was determined. Before aeration, $0.4 \mathrm{~m} \ell$ of pure culture or $0.7 \mathrm{~m} \ell$ in the case of the activated sludge were transferred to micro-centrifuge tubes to conduct DHA tests. Values of OUR for control samples and chlorine- or ozone-treated samples were correlated with the DHA and the plate count techniques.

In activated sludge, the $\mathrm{OUR}_{\text {(control) }}, \mathrm{OUR}_{\text {(chlorine) }}$ and OUR $_{\text {(ozone) }}$ were measured under the same conditions described before for pure cultures but substituting citric acid by the model wastewater of a potato processing plant as oxidisable substrate. 


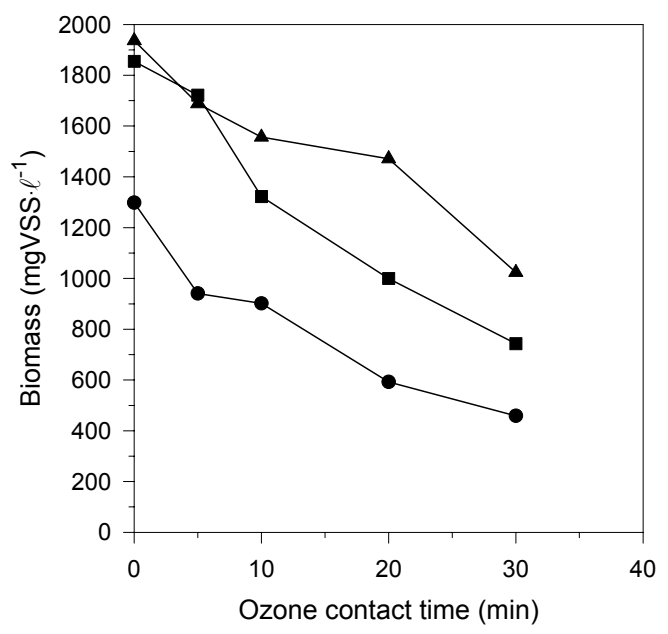

Figure 1

Biomass concentration of activated sludge as a function of ozone contact time $\left(26 \mu \mathrm{gO}_{3} \cdot \ell^{1}\right)$ for several initial biomass con-

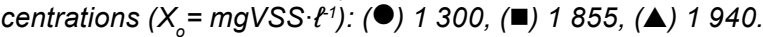

Samples of activated sludge resuspended in buffer phosphate $(15 \mathrm{~m} \ell)$ together with $5 \mathrm{~m} \ell$ raw wastewater were used in this case.

\section{Bacterial respiratory activity fraction}

In activated sludge, the biocide effect of the oxidising agents was determined from the ratio of metabolic activities in chlorineor ozone-treated samples and control samples. This ratio was defined as the bacterial respiratory activity fraction (FR).

FR obtained from the spectrophotometric technique $\left(\mathrm{FR}_{\mathrm{D}}\right.$ HAa) was evaluated as follows:

$$
F R_{D H A_{a}}=\frac{D H A_{a(\text { treated })}}{D H A_{a(\text { control })}}
$$

where:

$\mathrm{DHA}_{\text {a(treated) }}$ represents the spectrophotometrically measured-INT-dehydrogenase activity in both chlorination or ozonation treatments

$\mathrm{DHA}_{\mathrm{a}(\mathrm{control})}$ corresponds to the untreated samples.

FR of filamentous micro-organisms during chlorination or ozonation treatments was calculated by the -image analysis- technique $\left(\mathrm{FR}_{\mathrm{DHAi}}\right)$ as follows:

$$
F R_{D H A_{i}}=\frac{D H A_{i(\text { treated })}}{D H A_{i(\text { control })}}
$$

where:

$\mathrm{DHA}_{\mathrm{i} \text { (treated) }}$ and $\mathrm{DHA}_{\mathrm{i} \text { (control) }}$ correspond to treated (chlorine or ozone) and untreated samples respectively.

In the case of the respirometric technique, the following equation was applied to calculate FR:

$$
F R_{\text {OUR }}=\frac{\operatorname{OUR}_{(\text {treated })}}{\operatorname{OUR}_{(\text {control })}}
$$

where:

$\mathrm{FR}_{\text {OUR }}$ is the bacterial respiratory activity fraction based on OUR determinations for chlorinated or ozonated activated sludge

OUR $R_{\text {(control) }}$ is the control oxygen uptake rate

OUR $_{\text {(treated) }}$ corresponds to the values after chlorination or ozonation

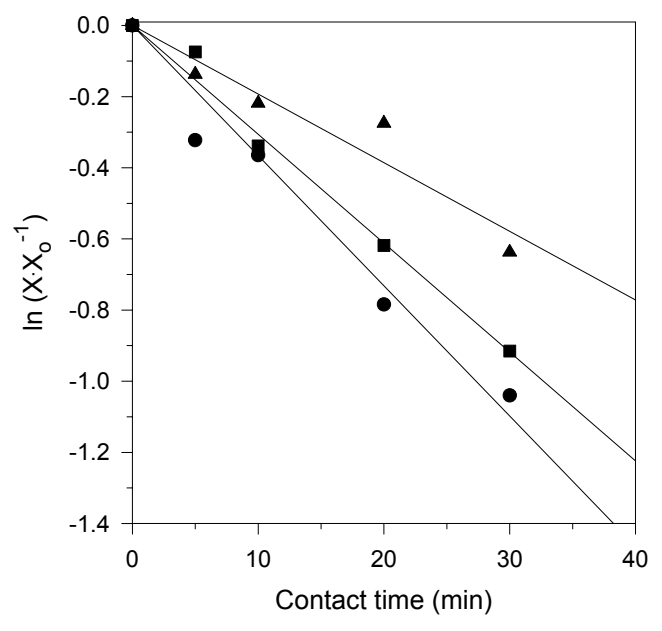

Figure 2

Plot of $\ln \left(X \cdot X^{-1}\right)$ vs. contact times with ozone ( $\left.\mathrm{min}\right)$ for various initial biomass concentrations $\left(X_{0}=\operatorname{mgVSS} \cdot \ell^{-1}\right)$ : $(\mathbf{0}) 1300$,

(घ) 1 855, (М) 1940. Lines represent Eq. (6).

\section{Statistical analysis}

Experiments were run in duplicate. Linear and non-linear regressions were obtained using Sigma Plot 2.0 software. Analysis of variance was done using Systat software. The Bartlett test to analyse variance homogeneity was applied in each case. The Student t-test was performed to compare regression coefficients (Zar, 1996).

\section{Results and discussion}

\section{Analysis of the effect of ozone on biomass concen- tration in activated sludge}

The activated sludge biomass concentration decreased almost linearly with the ozone contact time because this chemical agent oxidises various biomass components causing cell lysis. Examples of ozone effect on the decrease of biomass are shown in Fig. 1. Being a powerful oxidant, ozone inhibits microbial metabolism and reacts with several components of microbial biomass to cause structural changes, membrane deterioration and cell lysis (Hunt and Mariñas, 1999). For the initial biomass concentration range covered in these experiments (530 to $1940 \mathrm{mgVSS} \cdot \ell^{-1}$ ), the decrease of biomass concentration was modelled as a function of time with a first-order kinetic equation:

$$
\frac{d X}{d t}=-k X
$$

where:

$\mathrm{X}$ is biomass concentration $\left(\mathrm{mgVSS} \cdot \ell^{-1}\right)$

$\mathrm{k}$ is the specific rate of biomass decay $\left(\mathrm{min}^{-1}\right)$

$\mathrm{t}$ is the time (min).

By integrating Eq. (5), the following was obtained:

$$
\ln \left(\frac{X}{X_{o}}\right)=-k t
$$

where:

$\mathrm{X}_{\mathrm{o}}$ is the initial biomass concentration.

Eq. (6) provided a satisfactory description of experimental data (Fig. 2, $\mathrm{r}^{2}=0.95, \mathrm{p}<0.05$ ). 
Figure 3 shows the activated sludge biomass decay constant $\mathrm{k}$ as a function of the ozone dose rate (ODR) which varied from 2.4 to $8.8 \mathrm{mgO}_{3} \cdot \mathrm{gVSS}^{-1} \cdot \mathrm{min}^{-1}$ (initial biomass concentration: 530 to $\left.1940 \mathrm{mgVSS} \cdot \ell^{-1}\right)$. The decay constant $\mathrm{k}$ was related to ODR by the following relationship:

$$
k=\frac{a \text { ODR }}{b+\text { ODR }}
$$

As shown in Fig. 3, Eq. (7) fitted experimental data $(\mathrm{p}<0.05)$ and the following coefficients were obtained: $a=0.0748 \mathrm{~min}^{-1}$ (standard deviation $=0.0139$ ) and $\mathrm{b}=4.52 \mathrm{mgO} \cdot \mathrm{gVSS}^{-1} \cdot \mathrm{min}^{-1}$ (standard deviation $=1.65$ ); a being the maximum decay constant $\left(\mathrm{k}_{\max }\right)$. Thus, by means of Eq. (7), the decay constant $\mathrm{k}$ of activated sludge biomass can be calculated for any ozone dose rate belonging to the experimental range. Introducing Eq. (7) in Eq. (6) enables the biomass concentration of activated sludge (X) to be estimated as a function of time and ozone dose rate.

For example for an ODR of $6.1 \mathrm{mgO} \cdot \mathrm{gVSS}^{-1} \cdot \mathrm{min}^{-1}$ (initial biomass concentration $\left.=0.76 \mathrm{gVSS} \cdot \ell^{-1}\right)$ and $10 \mathrm{~min}$ of contact time $\left(\mathrm{D}_{\mathrm{oz}}=61.3 \mathrm{mgO}_{3} \cdot \mathrm{gVSS}^{-1}\right)$ the sludge biomass was reduced by $35 \%$ as estimated by Eq. (6).

In contrast, experiments showed that chlorine did not decrease the biomass concentration of activated sludge for the tested conditions: 3.3 to $6.0 \mathrm{mgCl}_{2} \cdot \ell^{-1}\left(\mathrm{D}_{\mathrm{Cl}}=4.7\right.$ to $\left.7.9 \mathrm{mgCl}_{2} \cdot \mathrm{gVSS}^{-1}\right)$ and 1 to 25 min contact times with chlorine. This is one of the aspects that has to be considered for the selection of an oxidising agent for filamentous bulking control.

As was previously indicated, chlorine was applied by using a sodium hypochlorite pulse to obtain the tested initial concentrations, however, chlorine concentration decreased with contact time because the reaction with the biomass. In a previous work, Caravelli et al. (2003) proposed a kinetic model considering that chlorine decay depends on the presence of readily oxidised organic matter $(Z)$ reacting at short contact times and on other compounds that react slowly and whose amount is directly proportional to the total biomass $\left(\mathrm{X}_{\mathrm{o}}\right): \mathrm{dC} / \mathrm{dt}=-\alpha_{\mathrm{z}} \mathrm{k}_{\mathrm{Z}} \mathrm{ZC}-\mathrm{kX}_{\mathrm{o}}{ }^{\mathrm{n}} \mathrm{C}^{2}$, where $\mathrm{C}$ is the chlorine concentration, $\mathrm{k}_{\mathrm{Z}}$ is the decay constant of the $Z$ component, $\alpha_{Z}$ is a stoichiometric coefficient which represents chlorine uptake per $\mathrm{Z}$ mass unit and $\mathrm{k}$ and $\mathrm{n}$ are empirical coefficients.

\section{Comparison of respirometry, DHA and plate counts using a pure culture of $A$. anitratus treated with chlorine or ozone}

Before comparing these techniques, it must be considered that the plate count technique quantifies the culture viability determined as total viable count, after a given chemical treatment, using a synthetic culture medium, whereas the metabolic activity parameters studied in the present work (DHA and OUR) determine, for the microbial culture analysed, the inhibition degree produced by the biocide agents on the biological degradation capacity of a given domestic or industrial wastewater.

The comparison of these techniques was carried out using pure cultures of $A$. anitratus obtained from a bioreactor operating under steady state conditions under defined growing conditions and the same morphological (free cells) and physiological conditions (dilution rates $=0.11$ to $0.13 \mathrm{~h}^{-1}$ ) in all the microbial inactivation assays using chlorine or ozone. Besides, the biomass concentration utilised in the different experiments was similar.

Linear correlations between DHA and OUR were found using pure cultures of $A$. anitratus treated with chlorine $\left(\mathrm{r}^{2}=0.945, \mathrm{p}<0.05\right.$, Fig. 4$)$ or ozone $\left(\mathrm{r}^{2}=0.940, \mathrm{p}<0.05\right.$, Fig. 4$)$

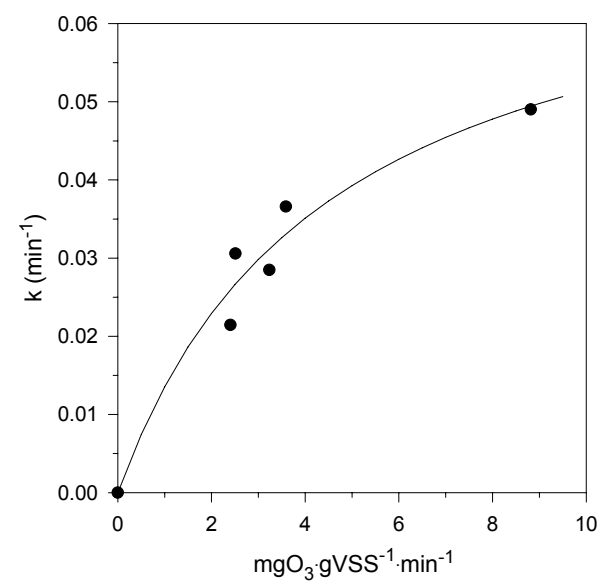

Figure 3

Relationship between biomass decay constant ( $k$ ) and ozone dose rate (ODR). (-) Experimental values. (-) Proposed equation (Eq. (7)).

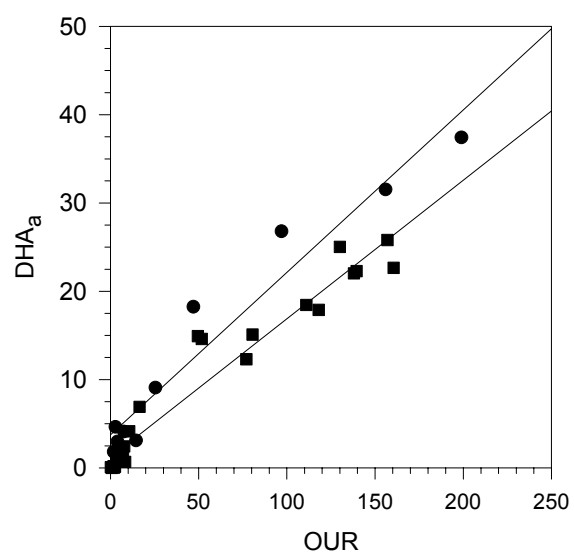

Figure 4

Relationship between INT-dehydrogenase activity measured by spectrophotometry $\left(D H A_{a}\right)$ and oxygen uptake rate (OUR) in pure cultures of A. anitratus treated with oxidant chemicals:

(•) Chlorine, (घ) Ozone.

thus the microbial respiratory activity can be determined with either of these techniques. The slopes of the regression straight lines were equivalent $(p>0.05)$, indicating similar effects of these oxidising agents on the OUR and the INT-dehydrogenase activity.

These results agree with literature data; different authors postulated that chlorine and ozone act on the cellular membrane where bacterial respiratory activity is produced. Chlorine causes inhibition of membrane-mediated active transport processes and respiratory activity (Camper and McFeters, 1979), uncoupling oxidative phosphorylation (Venkobachar et al., 1977). Ozone attacks the bacterial surface (Christensen and Giese, 1954) altering the permeability of the membrane (Scott and Lesher, 1963). Pryor et al. (1983) reported that proteins and unsaturated lipids in the bacterial membrane are the targets of the ozone attack.

Correlations between the plate count technique, respirometry and DHA test were also evaluated for A. anitratus pure culture exposed to chlorine or ozone. Figure 5 corresponds to $\log -\log$ graphs between CFU and OUR $\left(\mathrm{r}^{2}=0.866, \mathrm{p}<0.05\right.$, Fig. 5a) and between CFU and DHA $\left(\mathrm{r}^{2}=0.895, \mathrm{p}<0.05\right.$, Fig. $5 b$ ). In these graphs, the slopes of the regression straight lines for chlorine or ozone treatments are significantly differ- 


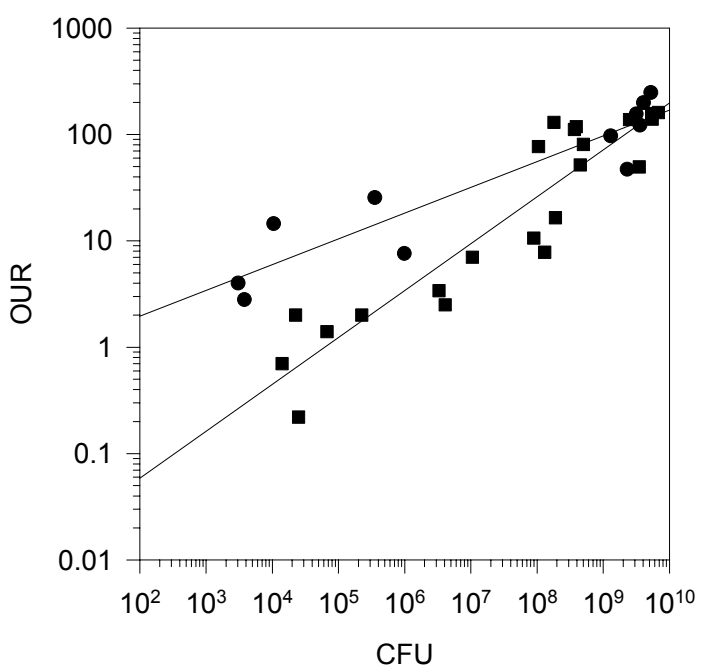

b

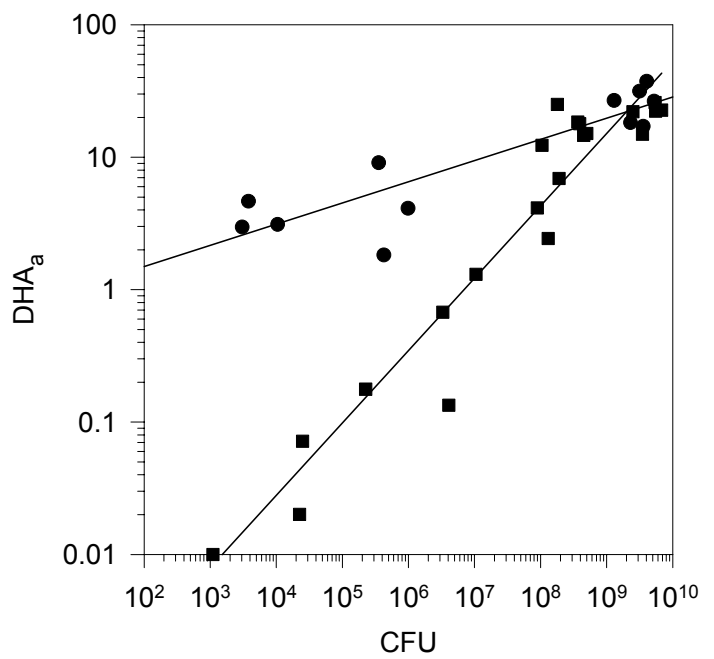

Figure 5

Relationship between colony forming units (CFU), oxygen uptake rate (OUR) and INT-dehydrogenase activity measured by spectrophotometry $\left(D H A_{a}\right)$ in $\mathrm{A}$. anitratus pure cultures under oxidant chemicals action. a) OUR vs. CFU. b) $D H A_{a}$ vs. CFU.

(•) Chlorine, (घ) Ozone.

ent $(p<0.005)$, suggesting that these oxidants have different toxicity mechanisms on the culture viability (as determined by plate count) and on the parameters of microbial metabolic activity studied in the present work (OUR and INT-dehydrogenase activity).

For relatively high microbial counts (Fig. 5a and b), high values of the bacterial respiratory activity were observed regardless of the oxidising agent used (chlorine or ozone). However, as the counts decreased (higher oxidant doses or longer contact times) a marked difference was observed between the metabolic activities after the two treatments: at the same microbial counts, the chlorine-treated culture exhibits higher respiratory activity (OUR and DHA ) than that observed after applying ozone; therefore, ozone antimicrobial action was stronger. With regard to this, different studies on inactivation of $E$. coli with ozone indicated that lysis of the cells can result for high concentrations or extended ozone contact times (Perrich et al., 1975; Hamelin et al., 1978). Hunt and Mariñas (1999) indicated that noticeable changes in the interior of $E$. coli cells did not take place until most of the cells were non-viable, while subsequent exposure to ozone resulted in structural changes, membrane deterioration, and ultimately lysis of the inactivated cells. More recently, Diao et al. (2004) reported that lysis of $E$. coli cells occurred during ozone disinfection of artificial wastewater; however, cell lysis was not noticeable for the chlorinated samples.

However, it is important to remark that a valid comparison between chlorine and ozone must be done using disinfection assays with the same water quality or wastewater effluent and with the same indicator micro-organisms in equal concentrations. Freese et al. (2003) reported that ozone produced better micro-organism removals at lower concentrations, and the disinfection reactions are more rapid with ozone compared to chlorine. Using a secondary wastewater effluent with a defined physical chemistry and biological composition, the dosages that provided adequate disinfection were $6 \mathrm{mg} \cdot \ell^{-1}$ for chlorine and $2 \mathrm{mg} \cdot \ell^{-1}$ for ozone. Similar results were found by Baker et al. (2002), who evaluated the effect of different oxidising disinfectants on pure cultures of micro-organisms (E. coli and H. pylori) resuspended in synthetic groundwater using batch contact reactor (where the oxidising agents are added at the start of the reaction). For $H$. pylori, the calculated $\mathrm{CT}_{99}$ values (concentration $\mathrm{x}$ time for $99 \%$ [2-log] reduction in viable organisms) were $0.299 \mathrm{mg} \cdot \ell^{-1} \cdot \mathrm{min}$ for chlorine and $0.24 \mathrm{mg} \cdot \ell^{-1} \cdot \mathrm{min}$ for ozone. For E. coli, the $\mathrm{CT}_{99}$ values were $0.119 \mathrm{mg} \cdot \ell^{-1} \cdot \mathrm{min}$ for chlorine and $0.09 \mathrm{mg} \cdot \ell^{-1} \cdot \mathrm{min}$ for ozone. Thus, ozone was more effective than chlorine for both micro-organisms; Von Gunten (2003) concluded that ozone is the most efficient disinfectant currently applied in drinking water treatment.

At a chlorine dose of $8.6 \mathrm{mg} \cdot \ell^{-1}$ Hassen et al. (2000) were able to achieve $1.75-\log$ reduction ( 5 min contact time) and 2.65 $\log$ reduction (10 min contact time) of faecal coliforms in secondary wastewater using a batch laboratory reactor. Xu et al. (2002), working with a continuous-flow pilot plant fed with secondary effluents, achieved 1.82-log reduction of faecal coliforms applying a transferred ozone dose of $8.6 \mathrm{mg} \cdot \ell^{-1}$ and a hydraulic retention time (HRT) of $4 \mathrm{~min}$, and 2.52-log reduction with a transferred ozone dose of $11.0 \mathrm{mg} \cdot \ell^{-1}$ and a HRT of $9.6 \mathrm{~min}$. Even though the initial number of faecal coliforms was similar in both studies, the comparison of the results has to be done very carefully because the reactors and the physico-chemical characteristics of the wastewater are different.

Considering that biomass activity indicates the ability of micro-organisms to metabolise a particular substrate (Gikas and Livingston, 1998), the application of tests based on metabolic activity determination (OUR and/or DHA $)$ is of great importance to monitor the behaviour and performance of activated sludge systems during filamentous bulking control using oxidising agents.

\section{Analysis of the effectiveness of oxidising agents for controlling filamentous bulking in activated sludge}

In activated sludge, the effects of the oxidising agents (chlorine and ozone) on microbial respiratory activity were analysed.

Figure 6 ( $a$ and $b$ ) shows the effect of chlorine and ozone doses and contact time on bacterial respiratory activity fraction (FR) in activated sludge measured by different methods: the respirometric technique $\left(\mathrm{FR}_{\mathrm{OUR}}\right)$, the spectrophotometric DHA test $\left(\mathrm{FR}_{\mathrm{DHAa}}\right)$ and the image analysis DHA test $\left(\mathrm{FR}_{\mathrm{DHAi}}\right)$.

The respirometric technique and DHA test allowed the evaluation of the inhibitory action of the oxidising agents on the total respiratory activity of the whole activated sludge $\left(\mathrm{FR}_{\mathrm{OUR}}\right.$ and $\mathrm{FR}_{\mathrm{DHAa}}$ ), while $\mathrm{DHA}_{\mathrm{i}}$ assay allowed evaluation of the specific effect of the oxidising agents on the respiratory activity of filamentous micro-organisms present in the flocs $\left(\mathrm{FR}_{\mathrm{DHA}}\right)$. 
a

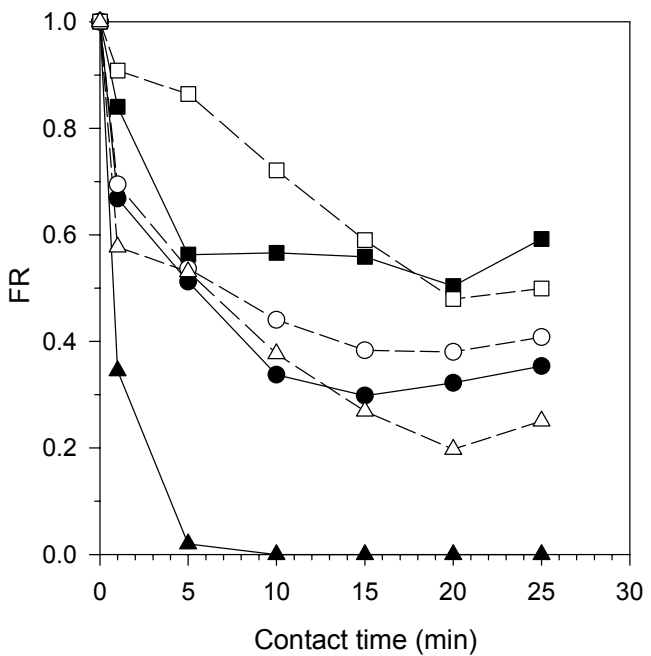

b

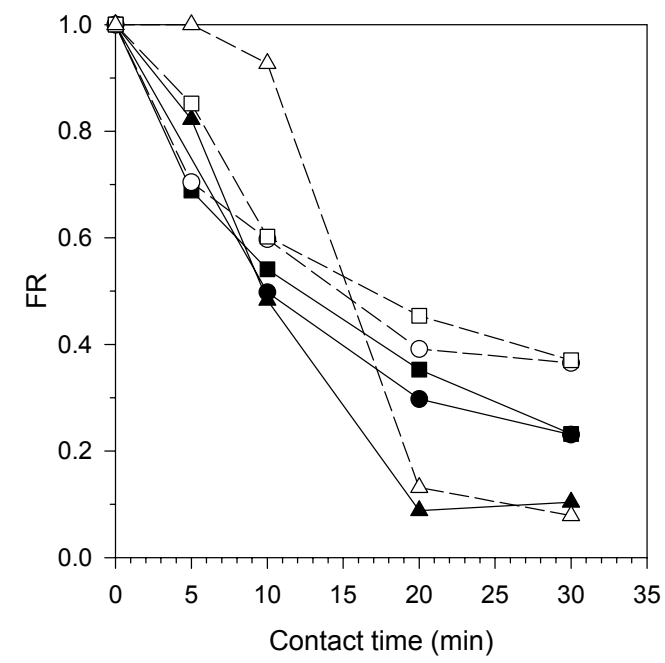

Figure 6

Effect of chlorine and ozone doses and contact times on bacterial respiratory activity fraction (FR) in activated sludge. $F R_{\text {OUR: }}$ : $F R$ based on respirometric technique, $F R_{D H A}: F R$ obtained by spectrophotometry, $F R_{D H A:}: F R$ obtained by image analysis.

a) Chlorine dose $\left(\mathrm{mgCl}_{2} \cdot \mathrm{gVSS}^{-1}\right)=4.7 \mathrm{mgCl}_{2} \cdot \mathrm{gVSS}^{-1}$ :

(O) $F R_{\text {OUR }},(\square) F R_{\text {DHAa }},(\Delta) F R_{D H A i} ; 7.9 \mathrm{mgCl}_{2} \cdot \mathrm{gVSS}^{-1}$ : (๑) $F R_{\text {OUR, }}$,

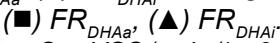

b) Ozone dose rate $\left(\mathrm{mgO}_{3} \cdot \mathrm{gVSS}^{-1} \cdot \mathrm{min}^{-1}\right)=3.3 \mathrm{mgO}_{3} \cdot \mathrm{gVSS}^{-1} \cdot \mathrm{min}^{-1}$ :

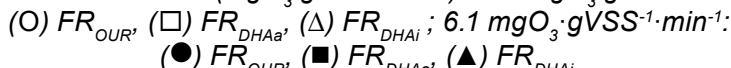

To optimise the use of oxidants when controlling filamentous bacteria present in activated sludge, conditions leading to low $\mathrm{FR}_{\mathrm{DHAi}}$ and high $\mathrm{FR}_{\mathrm{OUR}}$ and $\mathrm{FR}_{\mathrm{DHAa}}$ must be selected in order to inhibit filamentous micro-organisms maintaining the activity of the other micro-organisms in the floc.

Experiments at different contact times were carried out using different initial chlorine concentrations. For an initial chlorine dose $\left(\mathrm{D}_{\mathrm{Cl}}\right)$ of $4.7 \mathrm{mgCl} \cdot \mathrm{gVSS}^{-1}\left(3.3 \mathrm{mgCl}_{2} \cdot \ell^{-1}\right)$ and 20 min contact time (Fig. 6a), the bacterial respiratory activity fraction of activated sludge determined by respirometry $\left(\mathrm{FR}_{\mathrm{OUR}}\right)$ was 0.4 and that determined by spectrophotometry $\left(\mathrm{FR}_{\mathrm{DHAa}}\right)$ was 0.5 , while the value corresponding to filamentous micro-organisms in activated sludge measured by image analysis $\left(\mathrm{FR}_{\mathrm{DHAi}}\right)$ was about 0.22 . These results show that chlorine inhibited the respiratory activity of whole activated sludge by $50 \%\left(\left(1-\mathrm{FR}_{\mathrm{DHAa}}\right) 100\right)$ or $\left.60 \%\left(1-\mathrm{FR}_{\mathrm{OUR}}\right) 100\right)$, and the respiratory activity of filamentous micro-organisms was specifically reduced by $78 \%\left(\left(1-\mathrm{FR}_{\mathrm{DHAi}}\right) 100\right)$.

For $\mathrm{D}_{\mathrm{Cl}}$ of $7.9 \mathrm{mgCl}_{2} \cdot \mathrm{gVSS}^{-1}\left(6.0 \mathrm{mgCl} \cdot \ell^{-1}\right)$ and $5 \mathrm{~min}$ contact time (Fig. 6a), $F_{\text {OUR }}$ was $0.52, F_{\text {DHAa }}$ was 0.56 while $F_{\text {DHAi }}$ was about 0.02 , that represents an inhibition of 44 to $48 \%$ for the whole floc and of $98 \%$ for the filamentous micro-organisms. These were the most adequate conditions to considerably inhibit the respiratory activity of filamentous micro-organisms causing the lowest possible impact on whole floc metabolic activity.

In the case of ozonation, different experiments were conducted (Fig. 6b). For an ozone dose rate (ODR) of $3.3 \mathrm{mgO}_{3} \cdot \mathrm{gVSS}^{-1} \cdot \mathrm{min}^{-1}$ (initial biomass concentration $=1400$ $\operatorname{mgVSS} \cdot \ell^{-1}$ ) during a contact time of $20 \mathrm{~min}$ (total ozone dose, $\left.\mathrm{D}_{\mathrm{oz}}=66.0 \mathrm{mgO}_{3} \cdot \mathrm{gVSS}^{-1}\right), \mathrm{FR}_{\mathrm{OUR}}$ resulted $0.4, \mathrm{FR}_{\mathrm{DHAa}}$ was 0.46 while $\mathrm{FR}_{\mathrm{DHAi}}$ was found to be about 0.13 . Thus, ozone inhibited respiratory activity of activated sludge by 54 to $60 \%$ while the respiratory activity of filamentous micro-organisms was reduced by $87 \%$. Such ozonation conditions were suitable to control filamentous bulking. Additionally, under these ozonation conditions total sludge biomass was reduced by $46 \%$ as can be estimated by Eq. (6).

In contrast, an ODR of $6.1 \mathrm{mgO} \cdot \mathrm{gVSS}^{-1} \cdot \mathrm{min}^{-1}$ (initial biomass concentration $\left.=760 \mathrm{mgVSS} \cdot \ell^{-1}\right)$ applied for a contact time of $20 \mathrm{~min}\left(\mathrm{D}_{\mathrm{oz}}=122.0 \mathrm{mgO} \cdot \mathrm{gVSS}^{-1}\right)$ led to the following parameters: $\mathrm{FR}_{\mathrm{OUR}}=0.30, \mathrm{FR}_{\text {DHAa }}=0.36$, and $\mathrm{FR}_{\text {DHAi }}=0.09$. The sludge RA inhibition percentage produced by this treatment ranged between 64 to $70 \%$ while reducing RA of filamentous micro-organisms by $91 \%$. These ozonation conditions led to an excessive inhibition of the total RA of activated sludge and were considered inadequate.

To obtain an adequate inhibition of the filamentous microorganisms in activated sludge flocs using chlorine or ozone, the total ozone dose $\left(66.0 \mathrm{mgO}_{3} \cdot \mathrm{gVSS}^{-1}\right)$ was approximately 8 times higher than the required initial chlorine dose $\left(7.9 \mathrm{mgCl}_{2} \cdot \mathrm{gVSS}^{-1}\right)$.

In the present work, we found conditions such as 7.9 $\mathrm{mgCl}_{2} \cdot \mathrm{gVSS}^{-1}\left(6.0 \mathrm{mgCl}_{2} \cdot \ell^{-1}\right)$ and 5 min contact time for which chlorine produced a $98 \%$ inhibition of the filamentous microorganisms with a lower impact on total respiratory activity of activated sludge (44 to $48 \%$ ) in comparison to ozone. Thus, dosages have to be selected carefully when chemical agents are used to control filamentous bulking.

\section{Conclusions}

- In activated sludge, ozone decreased total biomass concentration by oxidising various components and causing cell lysis. An equation was proposed to estimate biomass concentration of activated sludge as a function of time and ozone dose rate. Conversely, chlorine, in the doses tested, did not decrease the concentration of activated sludge biomass.

- In a pure culture of $A$. anitratus, chlorine and ozone produced similar effects on the OUR and on the INTdehydrogenase activity. Ozone was found to have more intense antimicrobial action. This result can be attributed to different toxicity mechanisms of the applied oxidants on the metabolic activity parameters and the culture viability quantified as CFU.

- In activated sludge, an initial chlorine dose of $7.9 \mathrm{mgCl}_{2} \cdot \mathrm{gVSS}^{-1}$ for a contact time of $5 \mathrm{~min}$ (initial pulse $\left.=6.0 \mathrm{mgCl}_{2} \cdot \ell^{-1}\right)$, and a total ozone dose of $66.0 \mathrm{mgO} \cdot \mathrm{gVSS}^{-1}$ (ozone dose rate of $3.3 \mathrm{mgO} \cdot \mathrm{gVSS}^{-1} \cdot \mathrm{min}^{-1}$ for a contact time of $20 \mathrm{~min}$ ) were the optimal conditions to noticeably restrain the respiratory activity of filamentous 
micro-organisms while having a moderate impact on the overall respiratory activity of activated sludge.

\section{Acknowledgements}

The authors gratefully acknowledge the financial support given by the Consejo Nacional de Investigaciones Científicas y Técnicas (CONICET), Universidad Nacional de La Plata, and Agencia Nacional de Promoción Científica y Tecnológica, ARGENTINA.

\section{References}

BAKER KH, HEGARTY JP, REDMOND B, REED NA and HERSON DS (2002) Effect of oxidizing disinfectants (chlorine, monochloramine and ozone) on Helicobacter pylori. Appl. Environ. Microbiol. 68 (2) 981-984.

BARBUSIŃSKY K and KOŚCIELNIAK H (1995) Influence of substrate loading intensity on floc size in activated sludge process. Water Res. 29 (7) 1703-1710.

BENARDE MA, SNOW WB, OLIVIERI VP and DAVIDSON B (1967) Kinetics and mechanism of bacterial disinfection by chlorine dioxide. Appl. Microbiol. 15 (2) 257-265.

BERTOLA N, PALLADINO L, BEVILACQUA A and ZARITZKY N (1999) Optimisation of the design parameters in an activated sludge system for the wastewater treatment of a potato processing plant. $J$. Food Eng. 40 (1) 27-33.

BUCHAN L (1983) Possible biological mechanism of phosphorus removal. Water Sci. Technol. 15 (3-4) 87-103.

BULLOCK CM, BICHO P, ZHANG Y and SADDLER JN (1996) A solid chemical oxygen demand (COD) method for determining biomass in waste waters. Water Res. 30 (5) 1280-1284.

CAMPER AK and McFETERS GA (1979) Chlorine Injury and the Enumeration of Waterborne Coliform Bacteria. Appl. Environ. Microbiol. 37 (3) 633-641.

CARAVELLI A, CONTRERAS EM, GIANNUZZI L and ZARITZKY N (2003) Modeling of chlorine effect on floc forming and filamentous micro-organisms of activated sludges. Water Res. 37 (9) 2097 2105.

CARAVELLI A, GIANNUZZI L and ZARITZKY N (2004) Effect of chlorine on filamentous micro-organisms present in activated sludge as evaluated by respirometry and INT-dehydrogenase activity. Water Res. 38 (9) 2395-2405.

CHRISTENSEN E and GIESE AC (1954) Changes in absorption spectra of nucleic acids and their derivatives following exposure to ozone and ultraviolet radiations. Arch. Biochem. Biophys. 51 (1) 208-216.

CONTRERAS EM, GIANNUZZI L and ZARITZKY NE (2000) Growth kinetics of the filamentous micro-organism Sphaerotilus natans in a model system of a food industry wastewater. Water Res. 34 (18) 4455-4463.

CONTRERAS EM, BERTOLA NC, GIANNUZZI L and ZARITZKY NE (2002). A modified method to determine biomass concentration as COD in pure cultures and in activated sludge systems. Water $S A$ 28 (4) 463-468.

CONVERTI A, ROVATTI M and DEL BORGHI M (1995) Biological removal of phosphorus from wastewaters by alternating aerobic and anaerobic conditions. Water Res. 29 (1) 263-269.

CRABTREE K and MCCOY E (1967) Zoogloea ramigera Itzigsohn, identification and description. Int. J. Syst. Bacteriol. 17 (1) 1-10.

DIAO HF, LI XY, GU JD, SHI HC and XIE ZM (2004) Electron microscopic investigation of the bactericidal action of electrochemical disinfection in comparison with chlorination, ozonation and Fenton reaction. Process Biochem. 39 (11) 1421-1426.

FACILE N, BARBEAU B, PRÉVOST M, and KOUDJONOU B (2000) Evaluating bacterial aerobic spores as a surrogate for Giardia and Cryptosporidium inactivation by ozone. Water Res. 34 (12) 32383246.

FREESE SD, BAILEY I and NOZAIC D (2003) The Evaluation Of Alternative Disinfection Processes For The Removal Of Protozoan Oocysts And Other Micro-organisms In The Treatment Of Final
Wastewater. WRC Report No 1030/1/03. Water Research Commission, Pretoria, South Africa.

GEHR R, WAGNER M, VEERASUBRAMANIAN P and PAYMENT $P$ (2003) Disinfection efficiency of peracetic acid, UV and ozone after enhanced primary treatment of municipal wastewater. Water Res. 37 (19) 4573-4586.

GIKAS P and LIVINGSTON AG (1998) Use of specific ATP concentration and specific oxygen uptake rate to determine parameters of a structured model of biomass growth. Enzyme Microb. Technol. 22 (6) $500-510$.

HAMELIN C, SARHAN F and CHUNG YS (1978) Induction of deoxyribonucleic acid degradation in Escherichia coli by ozone. Experientia 34 (12) 1578-1579.

HASSEN A, HEYOUNI A, SHAYEB H, CHERIF M and BOUDABOUS A (2000) Inactivation of indicator bacteria in wastewater by chlorine - A kinetics study. Bioresour. Technol. 72 (1) 85-93.

HUNT NK and MARIÑAS BJ (1999) Inactivation of Escherichia coli with ozone: chemical and inactivation kinetics. Water Res. 33 (11) 2633-2641.

ISHIZAKI K, MIURA K and SHINRIKI N (1987) Effect of ozone on plasmid DNA of Escherichia coli in situ. Water Res. 21 (7) 823827.

JENKINS D, RICHARD MG and DAIGGER GT (1993) Manual on the Causes and Control of Activated Sludge Bulking and Foaming $\left(2^{\text {nd }}\right.$ edn.). Lewis Publishers, Inc., Chelsea, Michigan.

KERDACHI DA and HEALEY JK (1987) The reliability of the cold perchloric acid extraction to assess metal-bound phosphate. In: Ramadori R (ed.) Phosphate Removal from Wastewaters. Pergamon Press, Oxford.

KIM C-W, KOOPMAN B and BITTON G (1994) INT-dehydrogenase activity test for assessing chlorine and hydrogen peroxide inhibition of filamentous pure cultures and activated sludge. Water Res. 28 (5) $1117-1121$.

LOGUE C, KOOPMAN B, ASCE M and BITTON G (1983) INT-reduction assays and control of sludge bulking. J. Environ. Eng. 109 (4) 915-923.

LÖTTER LH (1985) The role of bacterial phosphate metabolism in enhanced phosphorus removal from activated sludge process. Water Sci. Technol. 17 (11-12) 127-138.

MAURINES-CARBONEILL C, PERNELLE J-J, MORIN L, SACHON G and LEBLON G (1998) Relevance of the INT test response as an indicator of ETS activity in monitoring heterotrophic aerobic bacterial populations in activated sludges. Water Res. 32 (4) $1213-$ 1221.

MINO T, VAN LOOSDRECHT MCM and HEIJNEN JJ (1998) Microbiology and biochemistry of the enhanced biological phosphate removal process. Water Res. 32 (11) 3193-3207.

PEREIRA WE, HOYANO Y, SUMMONS RE, BACON VA and DUFFIELD AM (1973) Chlorination Studies 2: Reaction of aqueous hypochlorous acid with alpha amino acids and dipeptides. Biochim. Biophys. Acta 313 (1) 170-180.

PERRICH JR, McCAMMON LR, CRONHOLM LS, FLEISCHMAN M, PAVONI JL and RIESSER V (1975) Inactivation kinetics of virus and bacteria in a model ozone contacting reactor system. In: Rice RG, Pichet P and Vincent M (eds.) Proc. $2^{\text {nd }}$ Int. Symp. on Ozone Technology. Montreal Canada. International Ozone Institute, New York, NY. 486 pp.

PIRT SJ (1975) Principles of Microbe and Cell Cultivation. Blackwell, Oxford.

PRYOR WA, DOOLEY MM and CHURCH DF (1983) Mechanisms of the reactions of ozone with biological molecules: the source of toxic effects of ozone. In: Mustafa MG and Mehlman MA (eds.) Advances in Modern Environmental Toxicology. Ann Arbor Science Publishers, Ann Arbor, MI.

REYNOLDS G, MEKRAS C, PERRY R, and GRAHAM N (1989) Alternative desinfectant chemicals for trihalomethane control - A review. Environ. Technol. Lett. 10 (6) 591-600.

RODRIGUEZ GG, PHIPPS D, ISHIGURO K and RIDGWAY H F (1992) Use of a fluorescent redox probe for direct visualization of actively respiring bacteria. Appl. Environ. Microbiol. 58 (6) 1801-1808.

ROS M (1993) Respirometry of Activated Sludge. Technomic Publishing Inc., Lancaster, Basel. 
ROSLEV P and KING GM (1993) Application of a tetrazolium salt with a water-soluble formazan as an indicator of viability in respiring bacteria. Appl. Environ. Microbiol. 59 (9) 2891-2896.

SAAYMAN GB, SCHUTTE CF and VAN LEEUWEN J (1996) The effect of chemical bulking control on biological nutrient removal in a full scale activated sludge plant. Water Sci. Technol. 34 (3-4) 275-282.

SCHAULE G, FLEMMING H-C and RIDGWAY HF (1993) Use of 5-cyano-2,3-ditolyl tetrazolium chloride for quantifying planktonic and sessile respiring bacteria in drinking water. Appl. Environ. Microbiol. 59 (11) 3850-3857.

SCOTT DBM and LESHER EC (1963) Effect of ozone on survival and permeability of Escherichia coli. J. Bacteriol. 85 567-576.

SHARMA AK and VENKOBACHAR C (1979) Effect of prechlorination on coagulation of algae. Indian J. Environ. Health 21 (1) 16-22.

SHIH KL and LEDERBERG J (1976) Effects of chloramine on Bacillus subtilis deoxyribonucleic acid. J. Bacteriol. 125 (3) 934-945.

STANDARD METHODS (1992) Standard Methods for the Examination of Water and Wastewater (18 ${ }^{\text {th }}$ edn.). Am. Publ. Hlth. Assoc. (APHA), Washington, D.C.

SWITZENBAUM MS, PLANTE TR, and WOODWORTH BK (1992) Filamentous bulking in Massachusetts: Extent of the problem and case studies. Water Sci. Technol. 25 (4-5) 265-271.

TABOR PS and NEIHOF RA (1982) Improved method for determination of respiring individual micro-organisms in natural waters. Appl. Environ. Microbiol. 43 (6) 1249-1255.

TREE JA, ADAMS MR and LEES DN (2003) Chlorination of indicator bacteria and viruses in primary sewage effluent. Appl. Environ. Microbiol. 69 (4) 2038-2043.

VAN DER WAARDE J, KROONEMAN J, GEURKINK B, VAN DER WERF A, EIKELBOOM D, BEIMFOHR C, SNAIDR J, LEVANTESI $\mathrm{C}$ and TANDOI V (2001) Molecular monitoring of bulking sludge in industrial wastewater treatment plants. Proc. $3^{\text {rd }}$ IWA Int. Spec. Conf. on Micro-organisms in Activated Sludge and Biofilm Processes. Session XVIII. Rome, Italy. 425-433.

VAN LEEUWEN J (1992) A review of the potential application of nonspecific activated sludge bulking control. Water SA 18 (2) 101-106.

VAN LEEUWEN J and PRETORIUS WA (1988) Sludge bulking control with ozone. J. Inst. Water Environ. Manage. 2 (2) 223-227.

VANROLLEGHEM PA, KONG Z, ROMBOUTS G and VERSTRAETE W (1994) An on-line respirographic biosensor for the characterization of load and toxicity of wastewater. J. Chem. Technol. Biotechnol. 59 (4) 321-333.

VENKOBACHAR C, IYENGAR L and RAV AVSP (1977) Mechanism of disinfection: Effect of chlorine on cell membrane function. Water Res. 11 (8) 727-729.

VON GUNTEN U (2003) Ozonation of drinking water: Part II. Disinfection and by-products formation in presence of bromide, iodide or chlorine. Water Res. 37 (7) 1469-1487.

WANNER J (1994) Activated Sludge Bulking and Foaming Control. Technomic Publishing Company, Inc., USA.

WARD NR, WOLFE RL and OLSON BH (1984) Effect of pH, application technique, and chlorine-to-nitrogen ratio on disinfectant activity of inorganic chloramines with pure culture bacteria. Appl. Environ. Microbiol. 48 (3) 508-514.

WHITE GC (1999) Handbook of Chlorination and Alternative Disinfectants (4th edn.). Wiley, New York. 57-94.

WINKLER MA (1996) Tratamiento biológico de aguas de desecho. S.A. Limusa, México DF: Grupo Noriega Editores.

XU P, JANEX M-L, SAVOYE P, COCKX A and LAZAROVA V (2002) Wastewater disinfection by ozone: main parameters for process design. Water Res. 36 (4) 1043-1055.

ZAR JH (1996) Biostatistical Analysis (3 $3^{\text {rd }}$ edn.). Prentice Hall, Inc., New Jersey. 